\title{
A Bolt from the Blue in Kazuo Ishiguro's The Remains of the Day
}

M. Meghaa

Ph. D Scholar

Department of English (Aided)

Kongunadu Arts and Science College(Autonomous)

Affiliated to Bharathiar University

Tamilnadu, India

meghaamuraleedharan111287@gmail.com

Shobha Ramaswamy

Head, Department of English (Aided)

Kongunadu Arts and Science College(Autonomous),

Affiliated to Bharathiar University

Tamilnadu, India

\begin{abstract}
Kazuo Ishiguro, receiver of the Nobel Prize for Literature in the year 2017, isa

Nagasaki-born writer. He developed his writing career in the year 1982 and many of his novels have historical contextual ideas. The literary attributes of Ishiguro's works are acknowledged for his uniqueness in English writing and method. It blends the sequence of the plot, to the extraordinary subjectivity of the portrayal, and to the historical sensitivity which truly interweaves with the depictions. The nostalgic and evocative characteristics of his writings make him the master of prodigious artistic works. The renowned novel of Kazuo Ishiguro, The Remains of the Day, which bagged him the prestigious Booker Prize in the year
\end{abstract}


1989, portrays the psychological niceties associated with the protagonist of the novel, Stevens. Stevens is a butler who works under an aristocrat whom he revered the most at the beginning but later he was betrayed by knowing the facts of his lordship being associated with the Nazis during the World War. Through the Trauma Theory this paper anatomizes the traumatic experiences of the mind, ramifications of thoughts and also the restrained dealings of human nature.This theory investigates the effect of trauma in writings and society, by examining its mental, logical, and social criticalness. The novel relocates the inherent presence of the theory throughplenteous incidents and contemplates on Stevens' thoughts.

Keywords: Trauma theory, Psychoanalysis, mind, society, human nature, identity

\section{Introduction}

The Remains of the Day is Ishiguro's third novel and later was pictured into a successful movie in 1993. It is a narrative novel in which the story line is recounted by the protagonist Stevens an English butler who performed dedicated service to his two employers, Lord Darlington and Mr.Farraday. The fiction covers the constant flow of thoughts, memories and testimonies of his life. He is a person who has a slavish sense of duty and an extreme loyalty that leads to abstinence and hence results in the trauma of losing his dignity. At the end he finds the inflated definition for his tragic emotions as he has lost his human identityor rather dignity. This work is filled with the character's narration and his inner thought processes which link the present views of life and the past time; hence it weaves back and forth. The author'snarrative technique is similar to that of a pendulum that swings between dignity and duty. Stevens duty as a butler goes on well as he serves Lord Darlington, the American gentleman without disturbing his plans and also carries out necessary tasks. The novel portrays the dedication of Stevens proving that his devotion to his 
employer amounts to 'destructive obedience'. Holmes emphasizes, "The destructive behavior is a collective damage when people reacts with a general ideal that involves the denial of their own emotional needs". (Web. 14)

It is the outlook of a human being and not his deeds that unravels the mystery of his life. The tendency to interpret the interior processes of the human mind is an unavoidable meddling course which Kazuo Ishiguro in his novel shows his best as he discusses on this. The life journey of Stevens in this story appears to be very expectant with number of insinuations and hence it hits its stride. His long term professional service to his master Lord Darlington and the devotion to him bring numerous instances of sensational satisfaction. Lord Darlington is a gentleman whose political naivety and ethical weakness cause him to be disparaging of his own motherland. Stevens dedicated service to his master makes him grow with different thoughts which draw attention to the repressed trauma. It becomes a denial of his thoughts and desires. The spellbinding events that happen in the life story of the butler and the oscillation between his past and present life incidents throws light to the ramifications of psychoanalysis in the novel at its maximum level.

Most of the novels written by Kazuo Ishiguro reflect the themes of ethnicity, culture and the lifestyle of the Japanese. The same can be proved in his prominent novels such as $A$ Pale View of Hills, An Artist of the Floating World and so on. But some diversions can be found in the setting of The Remains of the Day since it comes away from Japan and sketches the primary theoretical movements. The paper explores the unexplored innate traumatic events in the novel. By applying the concept of enigmatic trauma combined with historical background and memory impacts, this novel can be the best fit for the study of Trauma Theory that lies behind the story. 
Enigmatic Trauma of a Devoted Butler

Kazuo Ishiguro never bothered about the plot or its background but he was much concerned with the wholesome development of characters and their interactions. Ishiguro has portrayed the protagonist in a way that the identity of an Englishman is revealed as crucible of his predicaments, particularly the enigmatic trauma of his past life. Stevens upholds the idea of human dignity with a magnitude, which was considered as the most significant attribute for an Englishman, because of his two lifetime inspirations-his father who was a butler and his master Lord Darlington: "Mr. Charles remembered marveling at how my father showed not one hint of discomfort or anger, but continued to drive with an expression balanced between personal dignity and readiness to oblige".(39) Further he remarks, "Let me say that Lord Darlington was a gentleman of great moral stature- a stature to dwarf most of these persons you find talking this sort of nonsense about him”. (132)

Darmadi opines that Stevens is attached to these two individuals emotionally and psychologically- hence the events that involved with the traumatic experiences in their lives definitely affect the mental state of Stevens. (352) His father Mr. Stevens Sr. who was the most perfect butler he had ever seen, finally succumbs to the age factor and his inability to continue his service blemishes Stevens in an enigmatic trauma. The pitiful moment over the death of Stevens Sr. is in the novelist's words, "Dropped down on to one knee and with head bowed seemed to be pushing at the trolley before him, which for some reason had taken on an obstinate immobility". (97)

Another intense depression occurred when Stevens realized that his idol Lord Darlington to whom he had served with loyalty for his lifetime had betrayed him. After the World War, Lord Darlington lost both his dignity and stature in the society and from other lords as well, for going against the country being a Nazi sympathizer. Hence he faced an 
undignified death of disapproval and this again leads Stevens to unbearable trauma. The turmoil that he undergoes while serving as a butler who does not want to lose his self-esteem amidst his duty is the major hassle within him.

The perception of this paper is to understand the significance of the character Stevens who undergoes a traumatic life and is interpreted in the lights of Trauma Theory. This theory initially evolved during the 1990s and it depended on the Freudian idea to build up a model of trauma that envisions an outrageous encounter which challenges the constraints of language and even cracks meaning by and large. Trauma Theory is a portrayal about the language and the memory, in approaching the individual and the society. These are the focal worries that characterize the field of trauma. Psychoanalytic speculations on trauma were interpreted with the contemporary theories like, Post Structural, Marxist, and Postcolonial Theory. It analyses and deciphers the interpretations and its belongings upon character and memory.Sandra. L. Bloom writes in her essay,Trauma Theory Abbreviated:

At the time of the trauma they [the subject] had become trapped in "speechless terror" and their capacity for speech and memory become separated. As a result, they have developed what has become known as "amnesia" of the traumatic event - the memory is there, but there are no words attached to it so it cannot be either talked about or even thought about. Instead, the memory presents itself as some form of non-verbal behavior and sometimes as a behavioral re-enactment of a previous event. (Web.6) In a peculiar manner, the traumatic occasion resembles the apparition appendage of the psyche which hurts with a volatile and unbearable torment, since the genuine reason for the trauma is frequently distant. Trauma Theory is not solidly defined in narrative memory and fact, at the same time it must strive to endorse a firm yardstick of reliability.

Trauma is depicted by mental over abundance which either stifles the memory of the occasion or super imposes it over the persons present, showing in capricious occasions. The 
Freudian idea of trauma uses the military metaphor of infiltration. As Karyn. L. Freedman writes in her essay The Epistemological Significance of Psychic Trauma:

In the wake of a traumatic event a victim's emotional state is volatile, to be sure, as she undergoes intense personal suffering, but this is only one side of the aftermath of psychic trauma-the shattered self. The other side is the shattered world view the consequence of trauma on the survivor's belie/about the world. After a traumatic event a survivor experiences a kind of cognitive dissonance as she is faced with a whole new set of beliefs that have cropped up, often very suddenly, which are inconsistent with previously held beliefs. (105)

The writings have a stake in this because it is effectively associated with molding aggregate human cognizance. It is effectively occupied with making an interpretation of the obscure into known boundaries or in endeavoring to understand the gap between traumatic people. The perception of trauma in a book takes into account, to be coordinated into new important frameworks. It also accounts a peripheral comprehension of the arcane in the cognition. The theory has achieved not just an insurgency of the study of meaning yet in addition has made new enthusiasm for the field of memory and its importance.

In his historical novel The Remains of the Day, Ishiguro tries to bring out the real essence of the story by collecting pieces of the past and to integrate it with the present. The novel sheds light in gleams into the relationships between the individual and collective memory, human's personal and patriotic identity. The life history of Stevens from Darlington Hall to West Country is a dramatized one which makes him to understand the multicomplex levels of consciousness in life. Ishiguro emphasizes this point by locating all the past deeds of the protagonist, unfolding it with the help of his past memories and the speculations of the narrator. The journey of Stevens, the starts and stops, its diversions, vacillations by which he exposes his own duplicity all prove that the story runs 
simultaneously through the mind of the narrator as well as mind of the reader. The following line highlights the real state of mind of Stevens which depicts the diversified circumstances that he travels through:

In the summer of 1956, Stevens', an ageing butler, has embarked on a six-day motoring trip through the West Country. But this holiday is disturbed by the memories of his past service to the late Lord Darlington, and most of all by the painful recollections of his friendship with the housekeeper Miss. Kenton. For the first time in his life, Stevens' is forced to wonder if all his actions were for the best after a sad and humorous love story and a witty meditation on the democratic responsibilities of the ordinary man.(2)

Stevens depicted himself as an ideal butler in his life. Exemplarily positions the flagon with a ruler, irons the paper page by page, pauses for a minute to take care of his moribund father, contacts him quickly and returns promptly to work, every such detail effectively catches the quintessence of an optimal butler. Yet, the opposite side of Stevens grieves the loss of Miss Kenton and neglects to concede the errors he made in his life. The same he mentions as, "You see I trusted. I trusted in his lordship's wisdom. All those years I served him, I trusted I was doing something worthwhile. I can't even say I made my own mistakes. Really one has to ask oneself - what dignity is there in that?" (43) When he meets Miss.Kenton and tries to explain himself, Miss. Kenton blames him with these words:

Do you realize, Mr. Stevens', how much it would have meant to me if you had thought to share your feelings last year? You knew how upset I was when my girls were dismissed. Do you realize how much it would have helped me? Why, Mr. Stevens', why, why, why do you always have to pretend? (110) 
This incident traces his pathetic life which in turn he assumes to be a dignified life, but it is one another failure for him. Bessel A. van der Kolk, has also mentioned as follows, "The essence of psychological trauma is the loss of faith that there is order and continuity in life. Trauma occurs when one loses the sense of having a safe place to retreat within or outside oneself to deal with frightening emotions or experiences." (86)

Miss Kenton shares with Stevens about her life and the decisions that she made. She is despondent over the same all through her life. She reveals that she could not cherish moments with her better-half even after a long span of their marital life together. As she confesses, Stevens says that his heart is breaking. It is a terrible moment in his life, but he fails to uncover to her that he also had and still has profound fondness for her. The point that neither his nor her lament is ever quieted makes the conclusion of The Remains of the Day strong and awful.

The loyal butler is unequivocally devoted to his master Lord Darlington and refuses to doubt him when a young Cardinal says that he had become the "pawn" of the Nazis. (222) When he heard this statement Stevens remarks transparently, "I'm sorry, sir, but I have to say that I have every trust in his lordship's good judgment”. (225) But this trust was evaporated by the closing scene on Weymouth pier, the moral image of Lord Darlington and his respect was taken away from Stevens' mind as seen in the following lines:

Lord Darlington wasn't a bad man. He wasn't a bad man at all. And at least he had the privilege of being able to say at the end of his life that he made his own mistakes. His lordship was a courageous man. He chose a certain path in life; it proved to be a misguided one. He chose a certain path in life, it proved to be a misguided one, but there, he chose it, he can say that at least. As for myself, I cannot even claim that. You see, I trusted. I trusted in his lordship's wisdom. All those years I served him, I trusted 
I was doing something worthwhile. I can’t even say I made my own mistakes. Reallyone has to ask oneself- what dignity is there in that? (243)

This statement gives a view that how miserably he has failed in his life. Stevens sees that in giving his master the undoubted trust, he has damned himself to a fate worse than that of his master for in leading a merely explicit existence; he has become that pawn to pawn. Stevens puts effort to maintain the professional dignity and it results in a curbed subjective distress. The novel thus reflects the emotional and painful recollections of a dignified man who has an ill priced possession for a man who has an enthusiastic professional errand. His tragedy is that his pursuit of greatness as a butler subsumes everything: his emotions, his critical faculties and his judgment.

\section{Summing Up}

Trauma Theory, as a holistic approach to discourse processing, offers an overarching framework that is particularly useful in investigating the emotional significance of the interaction between the reader and the text during literary discourse.The theory records the feeling and literary ideas and consolidates the traumatic experiences and considers the vicissitude of the numerous interpretations. Stevens' characterization throughout the novel is insightful and nostalgic. Stevens at long last separates during the night when he is perched on the dock, coming to finally the acknowledgment that he has betrayed himself all through his life. There are both literal and metaphorical deaths: bereavement of friends and family, and allegorical euthanasia of dreams and beliefs. In his deception he accepts that the past is a magnificent thing yet as the story advances and he slowly analyseshimself and understands that his life is a total camouflage. His life makes it clear for the readers to understand the significance of time for bereavement and to admit to agony. Stevens fails to realize this. Nevertheless, his adversity is also bound up with his feelings of betrayal and of guilt. 


\section{Works Cited}

Bloom, SandraL. "Trauma Theory Abbreviated.” Community Works. santuaryweb.com. 1999. Web. Oct.1999.

www.iheartenglish.pbworks.com/f/Trauma+Theory+Explained+14+pages.pdf.

Darmadi, D. “Emotion in Irving Karchmanr's novel Master of the Jin.”AICLL: Annual International Conference on Language and Literature. 1(1).351-56 (2018).Print.

Freedman, Karyn L. "The Epistemological Significance of Psychic Trauma."Hypatia21.2 (2006): 104-25. Print.

Holmes, F. M., Realisms, (2005)."Dreams and the Unconscious in the Novels of Kazuo Ishiguro"Eds. A. James and C. E. Sarah. The Contemporary British Novel. 11-23. Web. 3 June 2020.doi.org/10.1007/978-1-349-73717-8_2

Ishiguro, K. The Remains of the Day. London : Faber and Faber, 1989. Print.

Van der Kolk, Bessel A. "Traumatic Memories.” Trauma and Memory: Clinical and Legal Controversies. Eds. Paul S. Appelbaum, Lisa A. Uyehahara, and Mark R. Elin. Oxford:UP, 1997.Print 